\title{
Het nut van vervangingswaarde informatie voor bestuurlijke doeleinden
}

\author{
Verslag van een workshop
}

\section{Inleiding}

Van $18 \mathrm{t} / \mathrm{m} 20$ augustus j.l. vond aan de Vrije Universiteit te Amsterdam de door de redactie van het maandblad georganiseerde internationale workshop getiteld 'The Usefulness of current replacement cost information for managerial purposes' plaats. Het thema werd in vijf onderwerpen gesplitst, namelijk:

a. de fundamentele relatie tussen de vervangingswaarde en micro-economische beslissingsmodellen;

$b$. het nut van vervangingswaarde informatie voor de evaluatie van het gevoerde beleid (het beheersingsaspect);

c. het nut van vervangingswaarde voor de prijsstelling;

$d$. enige problemen met betrekking tot het meten van de vervangingswaarde;

$e . \quad$ enige relaties tussen externe financiële verslaggeving en interne rapportering.

Voor ieder van deze vijf onderwerpen werden twee papers geschreven die elk vanuit een verschillende optiek het desbetreffende onderwerp behandelden. De discussie na de presentatie van de papers werd telkens ingeleid door één der deelnemers.

Naast de redactieleden van het maandblad namen vijf managers, ieder van een grote Nederlandse onderneming, en 15 academici waaronder zes buitenlanders (respectievelijk afkomstig uit Engeland $(2 x)$, Israël, WestDuitsland, de Verenigde Staten van Amerika en Australië) deel aan de workshop. ${ }^{1}$

In dit artikel wordt per onderscheiden onderwerp een korte samenvatting van elk van de papers gegeven. ${ }^{2}$ Vervolgens wordt getracht eveneens per onderwerp een samenvatting te geven van de belangrijkste aspecten die tijdens de discussie aan de orde zijn gekomen.

\section{Het nut van vervangingswaarde informatie binnen een algemeen economisch beslissingskader}

Dr. Bromwich (University of Reading) analyseert in zijn paper de geldigheid van twee in de Angelsaksische literatuur veelvuldig gebruikte redeneringen die de theoretische ondergrond vormen voor de toepassing van de vervangingswaarde ter bepaling van de waarde der activa in de financiële verslag- 
geving. Deze twee redeneringen zijn:

$a$. die van de 'surrogate'-hypothese, waarbij varianten van het contante waarde-besluitvormingsmodel worden gebruikt om aan te tonen dat de vervangingswaarde indirecte maatstaven verstrekt voor economische winst en economische waarde. Dergelijke surrogaten worden nuttig geacht vanwege de praktische problemen die zich voordoen bij de toepassing van contante waarde-berekeningen;

$b$. die gebaseerd op 'value to the owner', waarbij de voordelen van het bezitten van (ondernemings)activa worden bepaald. Deze benadering vertoont sterke overeenkomst met Limperg's vervangingswaardetheorie waar hij uitgaat van de laagste van de vervangingswaarde en de opbrengstwaarde.

Gebruikmakend van modellen ontleend aan de micro-economische theorie inzake de prijsstelling gebaseerd op marginale kosten, komt Bromwich tot de conclusie dat de beide theoretische benaderingen slechts onder zeer speciale omstandigheden betekenis hebben.

De 'surrogate'-hypothese geldt alleen indien monopolie op de markt voor de eindproducten van een onderneming is gecombineerd met monopolie op de markt waarop de onderneming de activa aanschaft. Met betrekking tot de 'value to the owner'-redenering zijn deze speciale omstandigheden dat de onderneming:

- de optimale bedrijfsomvang heeft bereikt;

- produceert onder constante 'returns to scale';

- de activa koopt op een volkomen markt.

De paper van Dr. Goldschmidt (Tel Aviv University) behandelt de belangrijkste procedures en technieken voor de inflatiecorrectie van de financiële gegevens die benodigd zijn voor economische beslissingen. Daarbij wordt een nauwe relatie tussen de vervangingswaarde en de vermogenskosten benadrukt, waarmee de onscheidbaarheid tussen de waardering en de financiering van de activa wordt beklemtoond. Deze relatie wordt aangetoond voor zowel onder financiering met eigen vermogen als met vreemd vermogen, voor zowel de onderneming als geheel als voor afzonderlijke afdelingen, en voor investeringscalculaties en de beoordeling daarvan achteraf.

In de paper wordt een belangrijke regel afgeleid en toegepast:

- de vervangingswaarde der activa dient te worden gebruikt in samenhang met de pré-inflatie (of inflatie-vrije) vermogenskosten; dan wel als alternatief;

- de historische kosten der activa dient te worden gebruikt in samenhang met de nominale (actuele) vermogenskosten.

Hiermee wordt voorkomen dat er in de analyses en berekeningen sprake is van dubbeltellingen met betrekking tot de inflatiefactor.

Discussie

Een belangrijk gedeelte van de tijd beschikbaar voor de discussie van beide papers wordt in beslag genomen door het probleem van dubbeltellingen. In tijden van inflatie doet zich bij ondernemingen die in meer of mindere mate ter financiering van de activa gebruik maken van vreemd vermogen het probleem voor van dubbeltelling van de inflatiefactor bij verschillende 
calculaties waaronder investeringsberekeningen, kostprijsberekeningen, prijsstellingsberekeningen e.d. Verondersteld wordt dat de uit 1930 daterende Fisher-gelijkheid: $r^{*}=r+p$ geldigheid heeft. De nominale (actuele) interestvoet $\left(r^{*}\right)$ is samengesteld uit een reële interestvoet ( $r$ ) plus de verwachte inflatievoet $(p)$. Deze laatste vormt een compensatie voor de koopkrachtdaling van de hoofdsom van een lening.

Dubbeltelling van de inflatiefactor ontstaat nu door de actuele waarde van de activa (in de calculaties) te combineren met de actuele (nominale) rentevoet. Naarmate de inflatie hoger is, zijn de onjuistheden die hierdoor ontstaan in de verschillende calculaties des te erger. Het vermijden van deze calculatie-dubbeltellingen - en derhalve fouten - impliceert dat rekening dient te worden gehouden met de hierbovengenoemde regel van Goldschmidt: hetzij combinatie van de actuele waarde en de reële interestvoet dan wel combinatie van de historische waarde en de nominale interestvoet.

Indien deze regel niet wordt toegepast bij de calculaties dan betaalt de consument bijvoorbeeld de inflatie tweemaal. Bij toepassing van de vervangingswaarde (op orthodoxe wijze) worden de activa geherwaardeerd. In de prijzen van de producten van de desbetreffende onderneming betaalt de consument de herwaardering, alle financieringslasten en al het geld dat nodig is ter instandhouding van de fysieke productiecapaciteit. De consument betaalt de inflatie een tweede keer in de compensatie die de onderneming dient te betalen voor de koopkrachtdaling van het aangewende vreemd vermogen. $O p$ basis van onzuivere calculaties - vervangingswaarde èn actuele (nominale) rentevoet - betaalt de consument de inflatie tweemaal.

Het probleem van dubbeltellingen kan ook spelen bij investeringscalculaties indien bij deze calculaties zowel rekening wordt gehouden met de prijsstijging van het investeringsproject - en dientengevolge de afschrijvingen stijgen - als met de op basis van de actuele (nominale) interestvoet bepaalde vermogenskosten. Juist bij investeringscalculaties dient men te waken voor dubbeltellingen door de in de paper van Goldschmidt afgeleide regel toe te passen. Doet men dit niet dan worden op zich winstgevende investeringsprojecten op basis van foutieve calculaties afgewezen.

Zowel de interestlasten van het vreemd vermogen als de vervangingswaarde van de activa bevatten een inflatiecomponent.

Dit alles geldt onder de veronderstelling van de juistheid en de geldigheid van de Fisher-gelijkheid. Er is echter (nog) weinig empirisch bewijs dat de interestvoet volledig verwerkt is in en varieert met de inflatievoet.

Een tweede onderwerp dat uitgebreid in de discussie aan de orde komt is de 'gearing-adjustment'. Het lijkt een nogal gecompliceerd vraagstuk te zijn, waarbij de deelnemers aan de discussie niet altijd hun veronderstellingen en uitgangspunten expliciet maken. Het onderwerp vertoont een nauwe relatie met het vorige. De 'gearing-adjustment' bedoelt dubbeltellingen bij de winstbepaling op basis van actuele waardetoepassingen te voorkomen. Het gaat hierbij dus om gewone prijsveranderingen. Het betreft niet een herwaarderingsprobleem doch het gaat om de vraag welk gedeelte van de herwaardering als resultaat moet worden beschouwd. 
De 'gearing-adjustment' is een correctie ten gunste van de resultatenrekening. In het geval een onderneming de goederenactiva registreert op basis van actuele waarde betreft deze correctie het verschil tussen de bedragen voor afschrijvingen en goederenverbruik berekend op basis van actuele waarde en die berekend op basis van de historische kosten, voorzover de goederenactiva zijn gefinancierd met vreemd vermogen. De gedachte die hier achter zit is dat het gedeelte van de goederenactiva dat is gefinancierd met vreemd vermogen in feite niet behoeft te worden geherwaardeerd in het geval van prijsveranderingen omdat aflossing van dat vreemd vermogen in nominale bedragen plaats vindt.

Daar echter de registratie van de goederenactiva plaatsvindt op basis van actuele waarde wordt er bij de winstbepaling een correctie aangebracht die deze gerealiseerde prijsstijging tot uitdrukking brengt.

De problematiek rond de 'gearing-adjustment' kan met behulp van de layout van de resultatenrekening worden geadstrueerd.

\section{Verkopen \\ - Kosten van de verkopen (op basis actuele waarde) \\ $=$ Bedrijfsresultaat.}

Het bedrijfsresultaat is een belangrijk cijfer in het besturingsproces van een onderneming. Daar veel managers geen invloed op de financieringsstructuur van de onderneming hebben impliceert dat de resultaten los van deze structuur dienen te worden getoond. Vervolgens kan door de keuze van de financieringsstructuur de onderneming meer of minder winstgevend worden.

Voorzover de onderneming financiert met vreemd vermogen is in de kosten van de verkopen (op actuele waarde basis) een gedeelte begrepen dat niet noodzakelijk is om de onderneming op 'going-concern' basis in stand te houden en derhalve, in het geval er sprake is van prijsstijging, in principe als gerealiseerde winst kan worden uitgekeerd.

Door het aanbrengen van deze correctie wordt in de resultatenrekening een winst getoond die, indien deze volledig wordt uitgekeerd, de continuitteit van de onderneming niet in gevaar brengt.

De 'gearing-adjustment' (in geval van prijsstijgingen) corrigeert het bedrijfsresultaat voor de gerealiseerde resultaten die ontstaan door het in voorraad hebben van activa ('holding gains'). 
Illustratie:

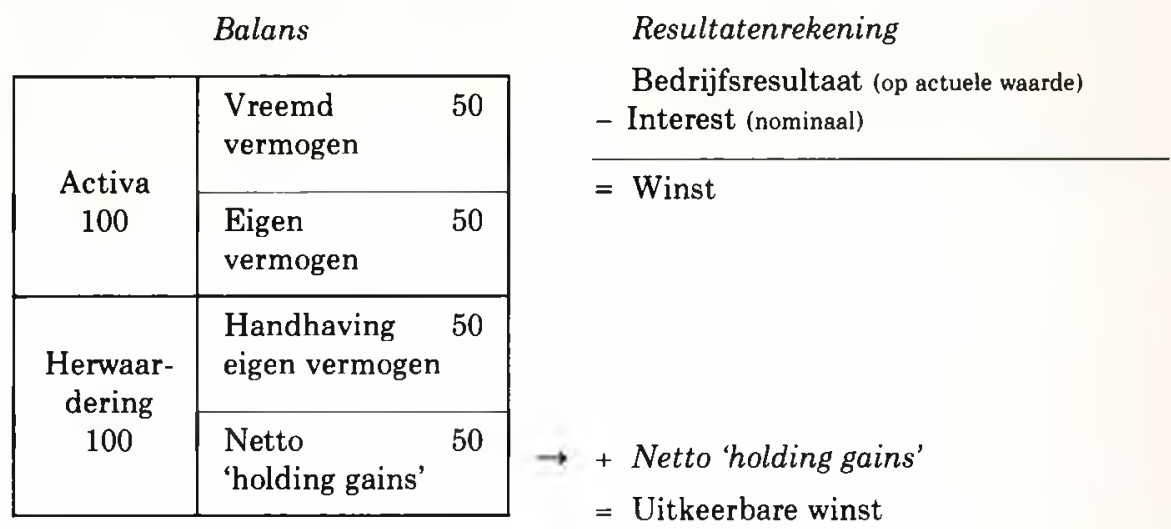

Een derde onderwerp tijdens deze discussie betreft de vraag of bij het meten van de prestaties van het management de 'holding gains' in de beschouwing dient te worden betrokken.

Een belangrijk voordeel van het toepassen van de vervangingswaarde in de financiële administratie is het onderscheid tussen de productieprestaties en de commerciële prestaties (inkopen en verkopen). Iedere manager die goederen activa koopt krijgt in perioden van inflatie te maken met "holding gains'. De vraag rijst hoe een onderscheid kan worden gemaakt tussen 'holding gains' die automatisch ontstaan a.g.v. het aanhouden van activa en die het gevolg zijn van kundigheden, n.l. het bewust eerder aankopen in een periode dat de prijzen gaan stijgen.

$\mathrm{Er}$ is echter niet één ondubbelzinnige wijze waarin de totale prestatie (productie en commercieel) van een manager kan worden uitgedrukt. Er dient rekening te worden gehouden zowel met het transactieresultaat op basis van de vervangingswaarde als met de gerealiseerde herwaardering begrepen in de kosten van de verkopen. Over beide aspecten wordt geoordeeld.

\section{Vervangingswaarde informatie en de evaluatie van het gevoerde beleid: het beheersingsaspect}

Dr. Traas (Vrije Universiteit) onderscheidt in zijn paper vier soorten prestaties: economische, management, financiële en strategische. Voor elk wordt nagegaan welke informatie in het kader van de beheersing van het ondernemingsgebeuren nodig is. Uitgangspunt in de analyse van Traas is dat bij marktentiteiten en bij winstcentra de aandacht in het beheersingsproces zich richt op twee belangrijke economische doeleinden:

$a$. het behalen van een toereikende winst gerelateerd aan het eigen vermogen;

$b$. het verkrijgen van voldoende geld om de toekomstige bedrijfsvoering te financieren.

Traas komt tot de conclusie dat informatie gebaseerd op de historische 
kosten toereikend is wanneer de economische, de management- en de financiële prestaties worden geëvalueerd. Alleen in het geval van het meten en beoordelen van de strategische prestaties speelt informatie gebaseerd op vervangingswaarde een rol.

Welke waarderingsgrondslagen voor beheersingsdoeleinden geschikt zijn wordt onderzocht in de paper van Dr. Kloock (Universiteit van Keulen). De aandacht wordt daarbij in belangrijke mate gericht op de beheersing van investerings- en financieringsprocessen. Kloock onderzoekt de betekenis van drie waarderingsgrondslagen: de verkrijgingswaarde, de huidige vervangingswaarde en de toekomstige vervangingswaarde. Centraal in de paper staat het zogenaamde 'Lücke-theorema', dat zegt dat, indien met betrekking tot een investeringsproject de winst uit verkopen gelijk is aan het verschil tussen de kasinstromen en de kasuitstromen, de contante waarde van het project gebaseerd op kasstromen gelijk is aan de contante waarde gebaseerd op kosten en opbrengsten.

Onder de veronderstelling van geldigheid van het Lücke-theorema stelt Kloock vervolgens de vraag welke substantie in een periode van inflatie in stand dient te worden gehouden. Hij concludeert dat dit de reële instandhouding van het vermogen is dat door de eigenaren is opgebracht. Op grond hiervan worden de kosten van de grondstoffen, de arbeid en de afschrijvingen afgeleid als de toekomstige vervangingswaarde ofwel de aankoopprijzen op het moment van de daadwerkelijke vervanging.

\section{Discussie}

Centraal in de discussie staat het vraagstuk van de instandhoudingsdoeleinden. Er bestaat een aantal instandhoudingsconcepten waarvan worden genoemd:

- handhaving van het oorspronkelijk geïnvesteerd (nominaal) vermogen;

- handhaving van de hoeveelheid fysieke kapitaalgoederen (handhaving productie- en verkoopcapaciteit);

- handhaving van de koopkracht van het geïnvesteerd vermogen.

Van belang is dat men zich daarbij realiseert dat de onderneming verantwoordelijkheden heeft tegenover o.a. de aandeelhouders, de werknemers, de afnemers, de leveranciers e.a. Als de onderneming niet in stand wordt gehouden dan worden deze verantwoordelijkheden genegeerd.

De vraag rijst wat het instandhoudingsdoel dient te zijn onder extreme omstandigheden, bijv. in een situatie met dalende verkoopprijzen als gevolg van wetenschappelijke en/of technologische omstandigheden. In zo'n situatie kan het voorkomen dat elk jaar op basis van vervangingswaarde een winst wordt berekend en er voor de aandeelhouders een acceptabel dividend wordt uitgekeerd. Als gevolg van de sterke daling van de verkoopprijzen echter daalt het eigen vermogen. Daar het prijsniveau van de aandelen zelden gelijk zal blijven indien de producten van de onderneming worden verkocht tegen extreem lage prijzen zal de aandeelhouder zijn oorspronkelijke inleg verliezen, hetgeen voor hem niet aanvaardbaar is.

De ondernemingsleiding daarentegen baseert zich, ook in dit geval, op de 'going-concern'-gedachte. De onderneming opereert in een bedrijfstak met een hoog risico. In zo'n geval zal niet alleen met hoge winstmarges dienen 
te worden gewerkt, maar ook met een lage winstuitkeringsquote. Dan is men in staat het eigen vermogen te handhaven.

De fundamentele vraag hierbij is in welke eenheid er dient te worden gerekend: in geld (M-G-M) of in goederen (G-M-G). Als in goederen wordt geregistreerd en gerekend dan rijst de vraag of men niet consequent dient te zijn en de realisatieconventie niet moet wijzigen. Daar in dat geval de totale transactiewinst pas bekend is op het moment dat de goederen daadwerkelijk zijn vervangen, dient dan niet op dat moment de winst te worden geregistreerd?

Een tweetal problemen dat in deze discussie naar voren is gekomen is echter onbeantwoord gebleven:

$a$. kan men als ondernemingsleiding de instandhoudingsdoelen definiëren alleen in termen van actuele kosten, of dient er tot op zekere hoogte ook rekening te worden gehouden met de nominale waarde van het in de onderneming geïnvesteerde vermogen?

$b$. in hoeverre dwingt de markt een bepaald instandhoudingsdoel af? Indien namelijk een onderneming in een markt opereert met bijv. veel Japanse concurrenten die alle hun prijsstelling baseren op historische kosten, is er dan voor die onderneming nog wel ruimte voor een substantialistisch instandhoudingsdoel?

Het wordt onjuist geacht om afhankelijk van de economische situatie - inflatie dan wel deflatie - de instandhoudingsdoelen te wijzigen.

Een tweede onderwerp dat in de discussie aan de orde komt heeft betrekking op het interne verslaggevingssysteem.

In het interne verslaggevingssysteem, mede ter beoordeling van de managementprestaties, zijn signalen nodig om te weten of er iets mis is. In een situatie waarin de prijzen dalen en er nog een marge is tussen de verkoopopbrengsten en de actuele kosten bestaat er een behoefte aan een signaal. Het is dan namelijk mogelijk dat er vanuit managementoptiek goede prestaties zijn geleverd, doch vanuit economische optiek geconstateerd dient te worden dat er iets mis is: de verkoopprijzen dalen. De verkoopopbrengst is niet alleen nodig ter dekking van de actuele kosten (inclusief vermogenskosten), maar ook ter compensering van het waardeverlies op het eigen vermogen. Omtrent de vraag in hoeverre winstrapportering op basis van vervangingswaarde het volledige plaatje geeft dat nodig is voor de beoordeling van de managementprestaties verschillen de meningen. Sommigen menen dat vervangingswaarde informatie voldoende is, anderen vinden dat dit niet het geval is.

Gedragsaspecten van interne verslaggeving vormen het derde onderwerp dat in de discussie is aangeroerd.

Wanneer de gedragsaspecten met betrekking tot de interne verslaggeving en de beoordeling van managementprestaties in de beschouwing worden betrokken dan dient dat niet te worden beperkt tot de statische invloeden van de min of meer stilzwijgend veronderstelde micro-economische theorie maar dienen evenzeer de dynamische invloeden een rol te spelen. Dit impliceert dat de invloeden van psychologische, sociologische, communicatieve en andere effecten van het intern verslaggevingssysteem dienen te worden meegenomen. 


\section{Het nut van vervangingswaarde in het kader van de prijsstelling}

Van der Zijpp (Universiteit van Amsterdam) bespreekt in zijn paper de aard van kosten- en prijsvergelijkingen binnen verschillende marktprocessen. Het hoofdthema in de paper is dat marketing een dynamisch proces is. Kosten vormen belangrijke gegevens ter beoordeling van prijzen uit het verleden en van de mogelijke toekomstige prijzen. Hoe kosteninformatie in verband staat met prijzen hangt af van het marktproces: de volgorde van gebeurtenissen en situaties die optreden in een gegeven marktstructuur (de min of meer constante aspecten van een markt).

Van der Zijpp beschrijft drie standaardprocessen: prijsconcurrentie, volledige kosten-prijsstelling en centrale prijsbeheersing. Daarnaast wordt in het kort aandacht besteed aan drie aspecten van marktontwikkeling: toenemende en afnemende vraag, verkoopbevordering en schaaleffecten.

Centraal in de paper van Dr. Wright (University of Melbourne) staat de bepaling van de in rekening te brengen minimumprijs, de zogenaamde 'reserve price'. Dit is de prijs waar beneden een product niet op de markt mag worden aangeboden vanuit het oogpunt van winstmaximalisatie.

Wright stelt dat de kosten uit het verleden irrelevant zijn voor rationele prijsbeslissingen. De relevante kosten zijn de toekomstige kosten, waarbij onderscheid wordt gemaakt naar de prijsstelling voor de korte en die voor de lange termijn.

Voor de korte termijn is de naastbije toekomst relevant. De minimumprijs dient dan gelijk te zijn aan de huidige vermijdbare kosten op basis van actuele standaardprijzen voor de korte termijn plus - in het geval van capaciteitsrandvoorwaarde - de 'opportunity-cost' van de capaçiteit.

De minimumprijs in het kader van de lange termijn prijsstelling hangt af van de totale kosten van de bedrijfsvoering met de laatst beschikbare economische efficiënte apparatuur, dan wel van die van binnenkort ter beschikking komende apparatuur.

De keuze met betrekking tot de korte termijn dan wel lange termijnvisie inzake een bepaalde prijsbeslissing hangt af van de mate van vrijheid die de onderneming heeft om regelmatig de prijzen te wijzigen. Deze vrijheid hangt op haar beurt in belangrijke mate af van de goodwill van de onderneming bij haar klanten in de markt waarvoor de prijs wordt vastgesteld.

\section{Discussie}

In de discussie volgend op de presentatie van beide papers wordt opnieuw aandacht besteed aan de instandhoudingsdoeleinden van ondernemingen. Daarnaast komt een aantal aspecten m.b.t. de prijsstellingsproblematiek bij enkele Nederlandse ondernemingen aan de orde en wordt een beeld geschetst van prijsstellingsproblemen binnen de I.A.T.A. Naar aanleiding hiervan wordt de vraag gesteld in hoeverre verkopers van de ondernemingsproducten kennis dienen te hebben van de kostprijs van het product en van de winstmarge. Het antwoord op deze vraag blijkt niet op ondubbelzinnige wijze te kunnen worden gegeven. Het is ondermeer afhankelijk van de bedrijfstak waarin de onderneming opereert. Wanneer een onderneming 
werkt op een markt met veel onzekerheid en er sprake is van hoge winstmarges dan is bekendheid van de kostprijs bij de verkopers niet belangrijk. Als zij die kostprijs wel kennen dan kan het gevaar ontstaan dat de verkopers niet het maximum uit de markt halen. Verkopers dienen kennis te hebben van prijzen, vooral die van de concurrenten.

In een consumptiegoederenindustrie, met hoge omloopsnelheden, snelle technologische veranderingen e.d., dienen de verkopers daarentegen wel inzicht in de kostprijs te hebben.

Een tweede aspect waaraan in de discussie aandacht is besteed betreft de relatie tussen de verkoopopbrengst en de afschrijvingen. De rationaliteit van de afschrijvingen ligt in het waardeverloop van de activa. Gewoonlijk wordt deze waarde niet beïnvloed door de verkoopopbrengst, in tegenstelling tot de onderhoudskosten die deze waarde wel beïnvloeden. Bovendien zijn verkoopopbrengsten geen element van kosten en dienen dan ook niet in het kostensysteem te worden opgenomen. Dit impliceert dat de verkoopopbrengsten niet in de bepaling van de afschrijvingen dienen te worden betrokken.

Tegen dit standpunt wordt ingebracht dat bij de bepaling van de afschrijvingen de verkoopopbrengsten wel degelijk in de beschouwing dienen te worden betrokken. Indien namelijk een onderneming een actief heeft dat vanwege technologische redenen de eerste jaren een hoge verkoopopbrengst geeft en in de latere jaren een lage dan zal in de eerste jaren een hoger bedrag worden afgeschreven dan in de latere jaren. Evenzo in het geval dat vanwege technologische redenen in de eerste jaren een hoge verkoopprijs en in de latere jaren een lage prijs geldt. Dus de verkoopopbrengsten - zowel qua prijsaspect als qua hoeveelheidsaspect - oefenen een invloed uit op de bepaling van de afschrijvingen.

\section{Enige problemen met betrekking tot het meten van de vervangingswaarde}

In zijn paper behandelt Dr. Peasnell (University of Lancaster) de gevolgen van technologische veranderingen voor de bepaling van de vervangingswaarde. Praktische problemen doen zich daarbij voor indien de accountant objectieve, marktbepaalde equivalenten (of 'proxies') voor de vervangingswaarde wil hanteren.

Allereerst worden in de paper geschetst de economische grondslagen voor de waardering van activa op basis van de vervangingswaarde en de hoofdlijnen voor deze waardering indien complicaties veroorzaakt door technologische vooruitgang afwezig zijn. Vervolgens worden de waarderingsgrondslagen in het geval dat er technologische veranderingen optreden besproken. Peasnell toont daarbij aan dat deze nauwelijks iets essentieels veranderen in de waarderingstaken van accountants. Hij levert daarbij tevens een bewijs - voor een onderneming met slechts één actief - dat de vervangingswaarde en de afschrijvingen hiervan kunnen worden bepaald zonder de hulp van arbitraire toewijzingen.

Voor het geval van een onderneming met meer activa wordt een oplossing geschetst. Voorts besteedt Peasnell aandacht aan de prijsstelling van pro- 
ducten in het geval het actief niet langer wordt voortgebracht.

Drs. Lock (C.B.S.) beschrijft in zijn paper de geschiktheid en de beschikbaarheid van indexcijfers voor het bepalen van de vervangingswaarde. Speciale aandacht wordt daarbij geschonken aan de mate van technologische verandering die in de indexcijfers dient te worden betrokken. Ook het concept van het zogenaamde algemene prijsindexcijfer wordt besproken. In het algemeen zijn drie soorten gegevens met betrekking tot prijsindexcijfers en prijzen beschikbaar:

a. de Laspeyres-prijsindexcijfers voor kapitaalgoederen (op een gedisaggregeerd niveau). Vanwege de hoge actualiteitswaarde zijn deze zeer geschikt voor het bepalen van de huidige vervangingswaarde van kapitaalgoederen;

b. deflatoren gebruikt in de Nationale Rekeningen. Deze zijn slechts beschikbaar voor algemene groepen goederen zoals gebouwen, machines e.d. Ze zijn in principe opgesteld volgens de Paasche-formule en vertonen een aanzienlijke 'time-lag';

c. 'Unit-value'-indexcijfers, afgeleid uit de statistieken van de buitenlandse handel. Deze indexcijfers worden berekend door per groep van goederen de waarde ervan te delen door de hoeveelheid. Hierbij doet zich het probleem voor dat per periode de samenstelling van het pakket van goederen aanzienlijk kan verschillen, waardoor het indexcijfer wordt beïnvloed. Ook kwaliteitsveranderingen worden niet geëlimineerd in dit indexcijfer. Dit vormt voor statistici redenen om de 'unit-value'-index als benadering van een prijsindex te verwerpen en het gebruik ervan voor het bepalen van de vervangingswaarde niet aan te bevelen.

\section{Discussie}

Het vraagstuk inzake het gebruik van indexcijfers bij toepassing van de vervangingswaarde vormt een belangrijk onderwerp tijdens de discussie van beide papers.

In het algemeen kan worden gesteld dat managers niet willen worden geconfronteerd met teveel indexcijfers. Men heeft behoefte aan een eenvoudig systeem, dat begrijpelijk is. Naarmate er meer indexcijfers worden gebruikt ontstaat verwarring. Indien aan managers wordt gevraagd - zoals in een Israëlisch onderzoek is gebeurd - of zij een algemene of een specifieke prijsindex willen, luidt hun antwoord: een algemene prijsindex. Wanneer specifieke indexcijfers ter bepaling van de vervangingswaarde van activa worden geintroduceerd dan is het niet denkbeeldig dat het uiteindelijke resultaat een index per manager is en wel die index die de desbetreffende manager het beste resultaat oplevert.

Een ander aspect van het vraagstuk algemene versus specifieke indexcijfers heeft te maken met de kosten. Hoe gedetailleerder de informatie des te hoger de kosten: er moeten meer berekeningen worden gemaakt. Met de voortdurende veranderingen in verslaggevingsprocedures dient men terughoudend te zijn bij het gebruik van te gedetailleerde indexcijfers. Het verdient aanbeveling de vraag algemene of specifieke indexcijfers ook te benaderen vanuit een kosten-batenanalyse.

Indexcijfers mogen niet worden gebruikt voor toepassingen waarvoor ze niet 
zijn bedoeld. Het C.B.S. heeft gekozen voor prijsindexcijfers. Deze mogen derhalve alleen worden toegepast in de context van prijsveranderingen. Daarnaast dient er voor te worden gewaakt dat subjectieve elementen in de statistieken worden geïntroduceerd. Alleen die zaken die objectief kunnen worden gemeten horen thuis in statistieken zoals indexcijfers.

Het wordt mogelijk geacht indexcijfers te berekenen die van zo'n aggregatieniveau zijn dat ze voor afzonderlijke ondernemingen als voor bedrijfstakken relevant zijn. Dit soort indexcijfers, van een tamelijk hoog aggregatieniveau zijn er (nog) niet.

Bij de bepaling van de vervangingswaarde van bestaande duurzame productiemiddelen in het geval dat een nieuwe technologie ter beschikking is gekomen, met behulp van indexcijfers kunnen problemen ontstaan. Indexcijfers voor bepaalde activa zijn zeer specifiek. Eén van de gevaren van het bepalen van de vervangingswaarde met behulp van prijsindexcijfers is de overwaardering van de desbetreffende activa. Het is een automatisch proces waardoor gemakkelijk te hoge waarden worden berekend vanwege de marktomstandigheden, de aanwezigheid van meer geavanceerde apparatuur, het verouderd raken van de bestaande capaciteit, e.d. Door het automatisme kan als gevolg van de stijgingen van het prijsindexcijfer de berekende vervangingswaarde van bepaalde activa niet in overeenstemming zijn met de werkelijke vervangingswaarde. De ontwikkeling van die prijsindexcijfers dient nauwgezet te worden gevolgd en indien nodig voor de eigen situatie te worden gecorrigeerd.

\section{Enige relaties tussen externe financiële verslaggeving en interne rapportering}

Dr. Revsine (North Western University, U.S.A.) onderzoekt in zijn paper de invloed van recente FASB-voorschriften betreffende het verstrekken van informatie inzake prijsveranderingen (FAS-33) op de interne rapportering en besluitvorming. Aan de hand van de resultaten van twee recente, in de U.S.A. gehouden, onderzoeken onder financiële managers van ondernemingen geeft hij een uiteenzetting van het interne (managerial) gebruik van op grond van FAS-33 gepubliceerde informatie. De behandeling hiervan valt uiteen in twee delen. In het eerste gedeelte bespreekt Revsine het gebruik van op basis van vervangingswaarde bepaalde, uit de bedrijfsvoering voortvloeiende winstcijfers waarbij de relevantie van deze winstcijfers voor diverse beslissingen (o.m. dividendbeslissingen, prijsstellingsbeslissingen e.d.) wordt onderzocht. Het tweede gedeelte geeft het gebruik van kostencijfers op basis van vervangingswaarde weer, bijv. ter bepaling van de prestaties van divisies, voor de investeringsselectie e.d.

Revsine veronderstelt dat het interne gebruik van 'inflation-accounting'informatie zal toenemen als managers meer omtrent de betekenis van deze informatie leren en vertrouwd raken met de interpretatie van de informatie. In de U.S.A. zijn reeds aanwijzingen hiervoor aanwezig.

In de laatste paper schetst Bak (Katholieke Hogeschool Tilburg) hoe een informatiesysteem er dient uit te zien als het systematisch een beeld behoort te geven van de resultaten van activiteiten gesplitst naar bedrijfs- 
resultaten en resultaten ontstaan als gevolg van het aanhouden van activa. In het algemeen speelt in de financiële verslaggeving de vervangingswaarde als een uitzondering, als additionele informatie, een rol. Bak keert in zijn paper dit om. Hij begint vanuit de veronderstelling dat een onderneming goede argumenten heeft om een op vervangingswaarde gebaseerd informatiesysteem te hanteren. Hij onderzoekt de invloed op dit informatiesysteem van een additionele wens inzake informatie gebaseerd op historische kosten.

\section{Discussie}

Een groot gedeelte van de tijd beschikbaar voor discussie naar aanleiding van deze twee papers is in beslag genomen door de vraag: voor wie of wat wordt de winst gemeten. $\mathrm{Bij}$ de beantwoording van deze vraag wordt onderscheid gemaakt tussen winst voor de onderneming en winst voor de aandeelhouder.

Winst voor de onderneming, gebaseerd op het entiteitsmodel, wordt weergegeven door de gelijkheid $\mathrm{A}=\mathrm{E}+\mathrm{V}$.

Winst voor de aandeelhouder, ook wel bekend als het bezitsmodel, wordt weergegeven door de gelijkheid $\mathrm{A}-\mathrm{V}=\mathrm{E}$.

In beide gelijkheden stelt $\mathrm{A}$ de activa, $\mathrm{E}$ het eigen vermogen en $\mathrm{V}$ het vreemd vermogen voor.

Bij de bepaling van de winst - in beide modellen - wordt uitgegaan van een zuivere fysieke kapitaalgoederen instandhouding.

In het model winst voor de onderneming bestaat de onderneming uit de A terwijl in het model winst voor de aandeelhouder de onderneming door $\mathrm{E}$ wordt gerepresenteerd.

Essentieel is dat bezien vanuit de conceptie van de onderneming het er niet toe doet op welke wijze de onderneming is gefinancierd, terwijl gezien vanuit de conceptie van de aandeelhouder dit wel van belang is. Daar gaat het er om over hoeveel vermogen die aandeelhouder beschikt. In de conceptie van winst voor de onderneming vormt een hogere interestvoet kosten van financiering. Bezien vanuit de conceptie van winst voor de aandeelhouder wordt dan daardoor de winst verlaagd.

Dit impliceert dat afhankelijk van welk gezichtspunt men heeft een ander winst-concept kan worden verdedigd. ${ }^{3}$

In het verdere verloop van deze discussie komt de nadruk te liggen op de conceptie winst voor de onderneming.

De gelijkheid $A=E+V$ geeft aan dat de activa, de fysieke productiecapaciteit, in stand dienen te worden gehouden, zowel aan het begin als aan het eind van de verslagperiode. De waarde van deze activa, op beide momenten, wordt met elkaar vergeleken.

Het aspect echter dat in het model $\mathrm{A}=\mathrm{E}+\mathrm{V}$ wordt gemist is dat de ondernemingsleiding niet alleen de $\mathrm{A}$, maar ook de $\mathrm{E}$ en de $\mathrm{V}$ bestuurt. Alle kosten die daaraan zijn verbonden betreffen de verantwoordelijkheid van de ondernemingsleiding. Veelal wordt de samenstelling van $E+V$ bepaald door de ondernemingsleiding. Nadat door die leiding dienaangaande een beslissing is genomen, wordt het bedrijfsresultaat op basis van vervangingswaarde berekend. Dat is de winst voor de onderneming. Als het 
resultaat positief is dan is er - op basis van vervangingswaarde - een goede prestatie geleverd. Er is een gelduitlener gevonden die bereid is geld te lenen waarmee de onderneming heeft gewerkt. Deze gelduitlener krijgt een vergoeding. Als er dan nog een winst resteert is er niet alleen op basis van vervangingswaarde een goed resultaat behaald doch is tevens - door geld relatief goedkoop te lenen - de winstgevendheid van de onderneming vergroot. Indien echter over $\mathrm{V}$ (vreemd vermogen) een hogere rentevergoeding moet worden betaald dan het resultaat dat met het gebruik van dit vermogen (en het eigen vermogen) is gerealiseerd, dan krijgt niet de gelduitlener de schuld doch de ondernemingsleiding.

Met betrekking tot de conceptie winst voor de onderneming zijn er twee verschillende verantwoordelijkheden die ten behoeve van beheersingsdoeleinden kunnen worden onderscheiden, namelijk $\mathrm{A}$ betreft de productie en $\mathrm{E}+\mathrm{V}$ de financiering. Beide activiteiten behoeven een verschillende expertise.

De lay-out van de resultatenrekening volgens SSAP-16 volgt dit stap voor stap. De interest daar dient te worden vergeleken met de 'gearing-adjustment'. Als de ondernemingsleiding met succes gebruik heeft gemaakt van financiering met vreemd vermogen - zo concludeert men in de discussie dan is in geval van inflatie het bedrag van de 'gearing-adjustment' waarschijnlijk lager (en positief) dan de interestpost.

\section{Vergelijking resultatenrekening volgens FAS- en SSAP-164}

\begin{tabular}{|l|c|c|}
\hline & FAS-33 & SSAP - 16 \\
\hline Bedrijfsresultaat (historische kosten) & 100 & 100 \\
Correcties op basis vervangingswaarde & 25 & 25 \\
- afschrijvingen & 15 & 15 \\
- kosten van de verkopen & - & 5 \\
- monetair werkkapitaal & $60^{*}$ & 55 \\
Bedrijfsresultaat (vervangingswaarde) & 20 & 20 \\
Interest & - & 15 \\
\cline { 2 - 3 } 'Gearing-adjustment' & $40^{*}$ & 50 \\
Bedrijfsresultaat vóór belastingen (vervangings- & 40 & 40 \\
waarde) & - & 10 \\
Belastingen & & \\
\cline { 2 - 3 } Bedrijfsresultaat na belastingen & & \\
\hline
\end{tabular}

* wordt normaal niet getoond

Het door Revsine in de discussie geïntroduceerde onderscheid tussen verwachte en onverwachte inflatie wordt door de meesten niet van belang hierbij geacht. 


\section{Afsluitende opmerkingen}

In het voorgaande is getracht een indruk te geven van de discussie naar aanleiding van de tijdens de workshop gepresenteerde papers. Terwille van de beperkte ruimte zijn de hoogtepunten uit de boeiende en soms ook scherpe discussies kort samengevat. Als gevolg van deze samenvatting is noodzakelijkerwijze informatie gecomprimeerd en is aan een aantal aspecten - veelal met een directe relatie tot de gepresenteerde papers - in dit artikel geen aandacht besteed.

De combinatie academische docenten en ondernemingsmanagers in deze workshop is, zoals dr. J. Klaassen in zijn samenvatting aan het slot opmerkte, een goede geweest en heeft de discussies zeer gestimuleerd. De academische docenten hebben een zeer belangrijk inzicht gekregen omtrent de wijze waarop managers de respectievelijk in de workshop aan de orde gekomen beslissingen nemen, welke informatie zij gebruiken, welke afwegingen zij maken. Aan de andere kant hebben de ondernemingsmanagers inzicht kunnen krijgen met betrekking tot de wijze waarop de academische docenten een greep trachten te krijgen op problemen die zij (nog) niet kunnen oplossen en waarvan zij weten dat deze (nog) niet op een optimale wijze kunnen worden opgelost. Door het stellen van lastige vragen aan de managers die deze problemen in de praktijk moeten oplossen kunnen de docenten weer een stap verder komen.

\section{Noten}

1 Voor de lijst van deelnemers zie pag. 196

2 Van de papers wordt een boek samengesteld, dat in najaar 1983 wordt uitgegeven door North Holland Publishing Company.

3 Zie biju L. Traas, De informatieve waarde van de jaarrekening, MAB, febr. 1976, pag 75-90. 4 Ontleend aan J. de Jong, An introduction to the discussion on 'Some relationships between external financial reporting and internal accounting'. 